\title{
Macroeconomic Determinants of Health Crises in Sub-Saharan Africa
}

\author{
Boyé Gnandé Roméo \\ Ivorian Center of Economic and Sociology Researches (CIRES), Côte d'Ivoire
}

Copyright $(2017$ by authors, all rights reserved. Authors agree that this article remains permanently open access under the terms of the Creative Commons Attribution License 4.0 International License

\begin{abstract}
The purpose of this article is to identify the macroeconomic determining factors of health crises. In order to reach our purpose, we use a logit model on a panel of 25 countries in sub-Saharan Africa from 1995 to 2012. The main results of this study indicate that international migration flows, the ratio of short-term debt by currency reserves, and the organization of the health care system explain health crises. These results imply that the poor management of information related to unforeseen events, the ability of reimbursement of the short-term debt, and the privatization of health services make most sub-Saharan African countries vulnerable to unforeseen events. This study suggests a better management of information related to unforeseen events, the increase of exportations and the improvement of the access to health services to all people during any unforeseen events outbreak.
\end{abstract}

Keywords Macroeconomics, Health crisis, Logit model, sub-Saharan Africa.

JEL Classification: E31, I18, C25.

\section{Introduction}

The unforeseen events like droughts, earthquakes, floods, storms and epidemics are natural phenomena. These phenomena also called natural shocks are difficult to predict and lead sometimes to health crises. Health crises have devastating consequences. According to Toma and Thiry [1] and Baylet [2], health crises are phenomena whose incidence goes beyond the usual epidemiological situation and lead to a flagrant decline in life expectancy. This flagrant decline in life expectancy, eventually, negatively impacts economic growth. Indeed, an enduring epidemic in the population leads to an increase in the overall mortality. This modifies the regime of long-term growth of the economy through the flow of available labor (Couderc, Drouhin and Ventelou, [3]). This is most often the case in developing countries (Poku, [4]; Dayton-Johnson, [5]). This situation is due to poverty that is the main determining factor of poor health (Subramanian, Belli, and Kawachi, [6]); thus, making people vulnerable to any type of shock (Sirven, [7]).

However, according to data from the World Bank, it is shown that in sub-Saharan Africa, countries like Benin and Niger have not experienced a decline in terms of life expectancy. Yet these countries have a lower standard of living compared to South Africa and Botswana. It should also be noted that neighboring countries such as Guinea and Sierra Leone, with about the same standard of living, do not respond in the same way to shocks related to epidemics (Rebaudet and Piarroux, [8]). In fact, during their study on the victims of cholera in 2012 in these two countries, these authors showed that the impact of this epidemic was stronger in Sierra Leone (293 deaths out of 22,815 cases) than in Guinea (138 Deaths in 7,351 cases). However, the GDP of Sierra Leone over the period is higher than the GDP of Guinea (1,591 USD for Sierra Leone compared to 1,197 USD for Guinea).

At the end of these observations, we ask ourselves the following questions. How do countries such as Benin and Niger, which are relatively poorer than countries such as South Africa and Botswana, have not been vulnerable to epidemics since their independence? While theoretically, most authors show that poverty leads to a multidimensional vulnerability (Dayton-Johnson, [5]; Sirven, [7]). On the other hand, why is there a heterogeneity in resilience to epidemics in some similar countries from the viewpoint of standard of living?

Genberg [9], Logie and Rowson [10], Touzé and Ventelou [11], Guillaumont et al. [12] show that macroeconomic management is the main determinant of health crises because poor macroeconomic management leads to inequalities, which in turn reinforce poverty and, consequently, the vulnerability to epidemics that leads to health crises.

So, what are these macroeconomic factors causing the occurrence of health crises?

The purpose of this study is to identify the macroeconomic determining factors of a health crisis. More specifically, the goal is to describe the mechanisms by which macroeconomic management affects health and to evaluate its impact in the 
occurrence of a health crisis.

This study will contribute to the stabilization of the budget allocated to public health. It is so important that it determines the levers on which governments must act in order to reduce the vulnerability of African nations to health crises; especially as these countries have been victims in recent decades of AIDS, cholera and Ebola epidemics.

If these epidemics are not made manageable, they will have important and lasting consequences on the health of individuals that could lead to health crises and at the same time inhibiting the effectiveness of the financial resources mobilized to reach the SDGs in the field of health.

\section{Determinants of Health Crises: A Review of Literature}

The first authors (Grossman, [13]; Pritchett et Summers, [14]; Bloom et Canning, [15]; Deaton [16], who have addressed the determinants of health status in general, show that it depends on the revenue, while others (Genberg, [9]; Logie and Rowson, [10]; Touzé and Ventelou, [11]; Guillaumont et al., [12]) believe that the health status of populations depends on the macroeconomic management, causing some countries to be more vulnerable to health crisis.

At the macroeconomic or macro-social scale, the threshold that characterizes the 'trap of human underdevelopment' due to health can be defined as a level below which irreversible situations of degradation or weakness of "Health capital" can be observed (Boidin and Lardé, [17]). According to the authors, health thresholds constitute, at the macro-social scale, situations such that a country can be blocked in a trap of human underdevelopment. Finally, they show that health thresholds are due, on the one hand, to shocks such as epidemics, and on the other hand, to indirect supply indicators such as the level of schooling, the access to drinking water, under-nutrition, and direct supply indicators such as the number of people working in health services.

In the case of diseases such as HIV/AIDS, the macroeconomic shocks are factors that accelerate the transmission of the disease through intra-national migratory flows (Touzé and Ventelou, [11]). Indeed, the coexistence of a poor population, deprived of economic activity, and of a rich population, well taken care of, and living with the virus for long, is also, in itself, a factor of propagation. Moreover, in the early 1980s, most countries in sub-Saharan Africa have been confronted with economic crisis which led to an increase of the rate of poverty; hence hunger and spread of HIV/AIDS (Basu, Mate and Farmer, [18]) and high mortality rate.

The organization of health care systems can also play a predominant role in the spread of epidemics (Van Dormaël, [19]), thus affecting the level of mortality depending on whether one adopts a certain type of health system (Bachand, [20]).
Birchenall ([21]) points out that in order to escape from very high mortality rates, the economic conditions and the standard of living of the populations in the northern countries must be improved. In the case of the countries of the South, the technological innovations in the field of health can help escape the high mortality rate. Sala-i-Martin ([22]) supports this result by arguing that significant investments in sanitation, for example, must be initiated in order to prevent the spread of malaria. Poor countries, unable to make these investments, will be condemned to use trivial techniques and will experience a high mortality rate.

Similarly, diseases such as cholera are associated with hygiene and poverty (Briggs, [23]; Rebaudet and Piarroux, [8]). At the Durban conference in South Africa in 2000, poverty was cited as one of the main sources of the spread of HIV/AIDS (Basu, Mate and Farmer, [18]). In fact, the fight against this disease is through the acquisition of health care, but the lack of financial resources and health infrastructures cause a problem according to President M'Beki (Basu, Mate and Farmer, [18]). Logie and Rowson ([10]) support that poverty, in all its forms, is the most important factor of poor health in the world today. According to authors, poverty leads to lack of access to drinking water, lack of hygiene, non-decent housings, low income and lack of access to health care services.

Farmer ([24]) shows that travel is an explanatory factor in the rise of diseases and their spread through viruses. However, diseases are transformed into a health crisis in certain areas, while in others, their spread are contained. This may be due to the inadequate health care structures in some countries (Basu, Mate and Farmer, [18]).

An external excess in debts may also be a factor in the occurrence of health crises. Indeed, payment of the debt takes all the money that was going to serve in importations and in health care system (Logie and Rowson, [10]). In addition, according to authors, the government's budget for health, education, and tentatives to reduce poverty is used for the payment of debt. Moreover, these authors think that countries in excess debt often use all bilateral and multilateral aid due to health crises. Finally, the excess of debt of developing countries is a prelude to episodes of economic crises.

Basu, Mate and Farmer ([18]) point out that debt and poverty transform the disease into an epidemic. Corruption is also an explanation for the increase in mortality as it negatively affects public health expenses. Indeed, Mookherjee ([25]) considers that a corrupt official is moved to a diligent search for fraudsters in the prospect of the bribe. However, Audibert et al. ([26]) show that corruption is not significant and does not act in a linear correlation on public health expenses. On the other hand, authors think that socio-political instability has a significant and negative impact on public health expenses. According to the authors, the greater the agitation, the more countries tend to allocate health's financial resources to other sectors which are more remunerative in terms of returning to social peace and keeping the authorities in power. 
Chauvet ([27]) shows that non-violent socio-political instability has a negative effect on aid given to middle-income countries. These instabilities are for the most part due to economic shocks (Miguel, Satyanath and Sergenti, [28]). Temah ([29]) shows, on a panel of 42 sub-Saharan African countries from 1997 to 2005 that the main determinants of the HIV/AIDS epidemic are income and gender inequalities. These inequalities are reinforced by inflation, which has a more negative effect on the poors (UNDESA, [30]).

According to Stillwaggon ([31]), the poors are biologically more vulnerable to HIV infection because they are malnourished and/or have parasitic infections that weaken their immune system. Xu and Saksena ([32]) find that, most of the time, when GDP increases, health expenses also increase. However, Farag et al. ([33]) show that health expenses respond poorly to a change in income in developing countries. During past financial crises, countries such as Thailand, Indonesia, Argentina and Russia have experienced a significant decline in public health expenses to the point where it took several years for these expenses to return to their pre-crisis level (World Bank, [34]).

Hailua and Shiferawb ([35]) show that the gap in financing of the economy and inflation lead to a dependence relative to external aid, which results in exposure to any shock.

This literature review can be schematized as follows:

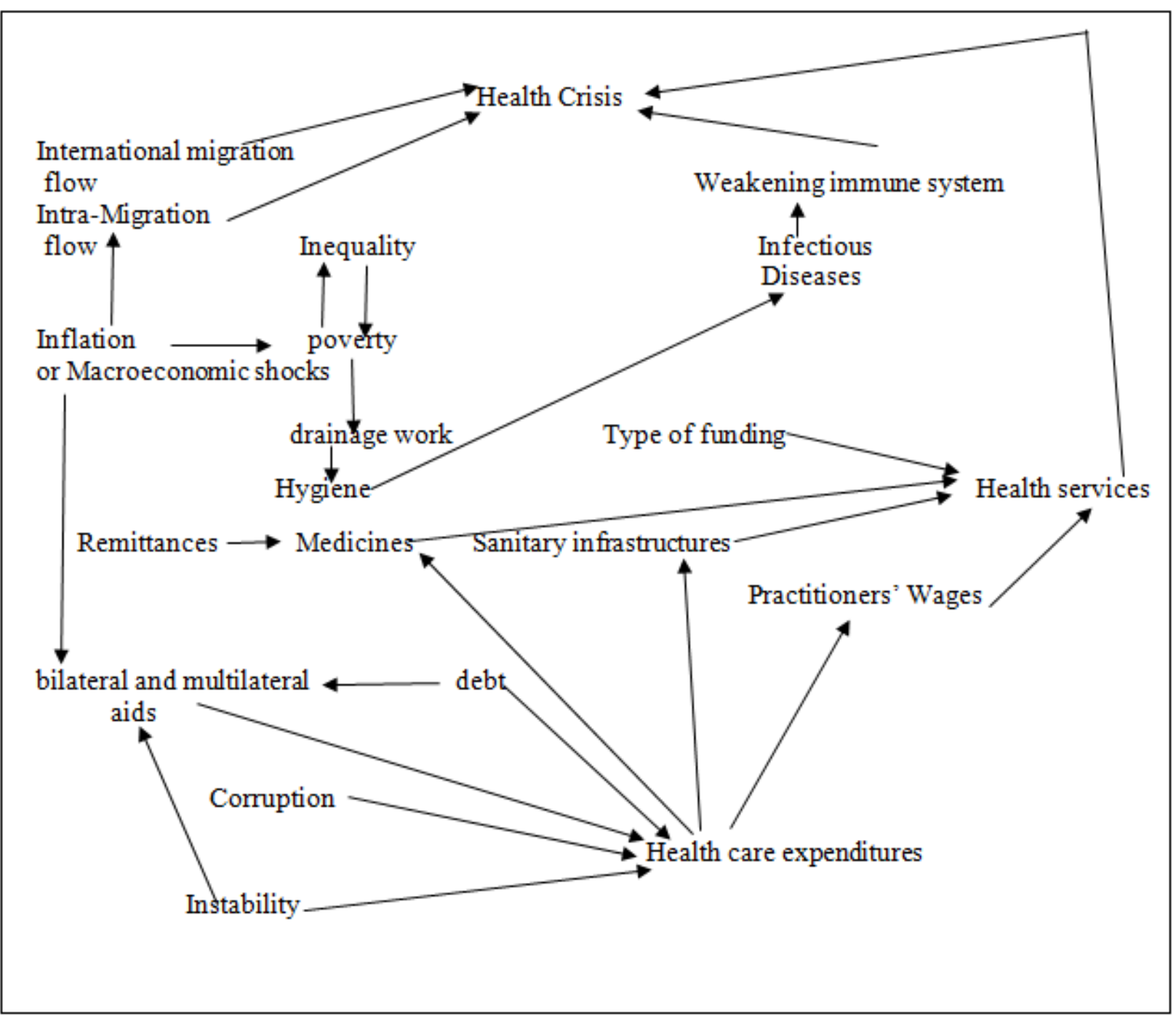

Source: author

Diagram 1. Factors favoring health crises 
This pattern shows that the variables likely to trigger vulnerability or resilience to epidemics are: inflation or macroeconomic shocks, debt, corruption, socio-political instability, monetary transfers, international migratory flows, type of health system that prevails.

According to the review of literature, most of studies in the field, have been limited to HIV/AIDS epidemic, Ebola, cholera and other epidemics. In this study, we take into account all these epidemics through their impact on life expectancy and we determine the common determining factors that trigger vulnerability to unforeseen events and leading to health crisis.

\section{Theoretical Framework of Analysis}

In this section, we construct the health crisis variable and highlight the theoretical model that will serve as the basis for the empirical assessment of the impact of the determining factors of health crisis.

\subsection{Specification of the Dependent Variable}

Toma and Thiry ([1]) refer to health crisis as the evolution of an emerging disease ${ }^{1}$, ie a disease whose actual incidence increases significantly in each population of a given region and during a given time, in relation to the usual epidemiological situation. Baylet ([2]) shows that the concept of emergence in this case reflects the recent appearance of an event or threat above a threshold considered critical. For the author, these emerging diseases are the leading causes of health crises. Hence, health crises are only the consequences of these diseases in terms of incidence.

To some extent, Toma and Thiry ([1]) suggest that the use of the term "emerging disease" should be reserved for diseases for which the actual increase has been "unusual". In sum, the consequences of an emerging disease will modify the trajectory of endemic incidences, ie the flagrant change in the mortality rate over the time period for example (Toma and Thiry, [1]) or life expectancy.

Based on the description of health crises, we define the period of health crisis as a continuous decline in life expectancy so that a change in its trajectory is observed. We schematize the episodes of health crises as follows:

1 An emerging disease may not be new and a new disease may not be emerging. Any disease due to an agent of "new appearance" does not, ipso facto, deserve the qualifier of emergent. The fact that it has just been identified or recognized, especially if its frequency remains low, is not enough to consider it as emerging. In other words, what is emerging is not the novelty in itself, but the increase in incidence.

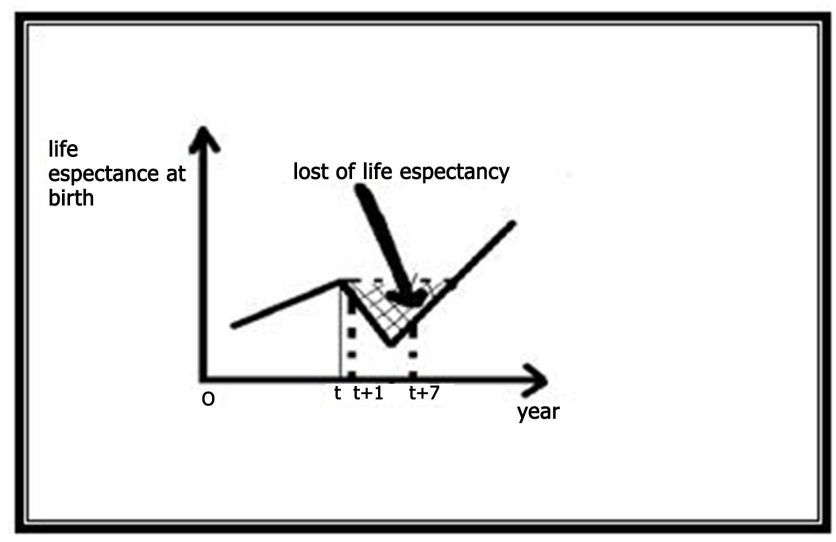

Source: author

Diagram 2. Characterization of a health crisis

The beginning of the health crisis is $t+1$ and the end is $t+7$, we conclude that the periods of crisis are $t+1, t+2, t+3, t+4$; $t+5$ and $t+6$. So we have six periods of crisis.

For Manasse, Roubini and Schimmelpfennig ([36]), the determining factors of the entrance in a crisis are different from those that explain the exit from a crisis; this justifies the interval indicated in the diagram above as period of health crisis in the case of this study.

\subsection{Theoretical Model}

We consider health crisis (d_crisis) as a function of macroeconomic variables $(M)$ and non-macroeconomic variables $(N M)$. The relationship between the health crisis and its determinants can thus be formulated as follows:

$$
\text { d_crisis= F }(\mathrm{M} ; \mathrm{NM})
$$

In equation (1), the macroeconomic variables include the inflation rate, the ratio of debt to total foreign exchange reserves, the reduction of debt, and net monetary transfer. The non-macroeconomic variables include the number of international tourists entering the country, the degree of freedom against corruption, conflicts (existence, typology and intensity) and type of health care system.

$d_{\text {c crisis }}$ is set to be equal to 0 if there is no decrease in life expectancy, and 1 if not. Thus, equation (1) becomes a model with binary variable as variable to be explained. Consider a continuous variable $d$ crisis $^{*} \in \mathfrak{R}$ such as $d_{\text {_crisis }}=1\left\{d_{\text {_ }}\right.$ crisis $\left.^{*} \geq 0\right\}$.

If we suppose that $d_{-}$crisis $^{*}$ follows a linear model of the form:

$$
d_{\text {crisis }}{ }^{*}=X^{\prime} \beta_{0}+\varepsilon .
$$

Where $\varepsilon$ the error is term and is independent of $\mathrm{X}$ and has the distribution function $F$, then:

$$
P\left(d_{\text {_crisis }}=1 \mid X\right)=P\left(X^{\prime} \beta_{0}+\varepsilon \geq 0 \mid X\right)=P\left(-\varepsilon \leq X^{\prime} \beta_{0} \mid X\right)
$$

If $P\left(d \_\right.$crisis $\left.=1\right)$ is the probability that we have a health 
crisis, then we have:

$$
P\left(d_{-} \text {crisis }=1 \mid X\right)=F\left(X^{\prime} \beta_{0}\right)
$$

Where $X$ is a vector composed of macroeconomic and non-macroeconomic variables. $\beta_{0}$ is the vector of the parameters of the model to be estimated. $F$ is a distribution function of $\varepsilon$ and can follow a normal law or a logistic law or some other law. However, in the literature, these are the normal and logistic laws that are the most used. Some differences may appear between these two laws when one of the occurrences of $d$ crisis is very rare, because the distribution tails of the two functions differ. In the case where one of the occurrences of $d$ _crisis is very rare, we opt for the logistic distribution function (Manasse, Roubini and Schimmelpfennig, [37]). In the contrary case, it is preferable to use the normal distribution. We can use the Poisson's law if the phenomena is only observed on an interval; this is not the case because some countries meet several intervals of periods of crisis.

\section{Methodological Approach}

The analysis in this study is conducted on a panel of 25 sub-Saharan African countries over the period 1995-2012. The choice of the period is justified by the fact that some explanatory variables do not exist before 1995 for all sub-Saharan African countries. The choice of the period is justified by the fact that some explanatory variables do not exist before 1995 for all countries in sub-Saharan Africa. In addition, the period 2013-2015 is reserved for forecasts.

Our approach will consist in analyzing successively the distribution of health crises in the sample of the study to choose the distribution law to adopt. Next, we will select the explanatory variables from the literature and mean difference tests. Then, we will do some correlation tests, and specify the empirical model of the study. Finally, we will adopt the appropriate estimation method.

\subsection{Data and Sources}

In this subsection, we construct and define the variables of the study. We also indicate their source.

\subsubsection{Construction of the Dependent Variable}

Based on the specification of the health crisis variable in the theoretical framework and life expectancy data from the World Bank's World Development Indicators (WDI) 2014 database, we constructed the dependent variable of the study as follows. For a given year, we make the difference between the current life expectancy and the life expectancy of the previous period. If this difference is negative, then we postulate that there is a health crisis at the current period. The episodes of health crises are recorded in Table 1 below.

Periods of health crisis account for slightly more than $20 \%$ of observations; ie 94 cases of decreases in life expectancy in the panel.

According to Manasse, Roubini and Schimmelpfennig ([36]), we opt for the logistic distribution function due to the fact that the occurrences of $d$ _crisis is very rare (20\%).

\subsubsection{Explanatory Variables}

The explanatory variables used to explain the occurrence of health crises arise from the literature review that was done above. These are variables likely to trigger vulnerability to unforeseen events. These include debt, monetary transfers, international migratory flows, inflation, corruption, the type of health care system and social instability.

We choose two debt indicators that are debt reduction and the ratio of short-term debt by total foreign exchange reserves. The variable instability is represented by one of the three conflict variables that are the existence of conflict, the intensity of the conflict and the type of conflict. International migratory flows are approximated by the number of international arrivals; because this variable is official and regular than the variable international migration. 
Table 1. Episodes of health crises in the overall sample since 1995

\begin{tabular}{|c|c|c|c|}
\hline Country & $\begin{array}{l}\text { Health crisis } \\
\text { experienced }\end{array}$ & Episodes of health crisis & Duration of episodes of health crisis (year) \\
\hline Benin & no & ----- & ----- \\
\hline Botswana & yes & $1995-2008$ & 14 \\
\hline Burkina Faso & no & ----- & ----- \\
\hline Cape Verde & no & ----- & ----- \\
\hline Cameroun & yes & $1995-2003$ & 9 \\
\hline Congo, Rep. & yes & 1995-1999 & 5 \\
\hline Côte d'Ivoire & yes & $1995-2001$ & 7 \\
\hline Ethiopia & no & ----- & ---- \\
\hline Gabon & yes & $1995-2002$ & 8 \\
\hline Ghana & yes & 1995-1999 & 5 \\
\hline Guinea & yes & $1996-2000$ & 5 \\
\hline Kenya & yes & $1995-2001$ & 7 \\
\hline Lesotho & yes & $1995-2004$ & 10 \\
\hline Malawi & yes & 1995-1999 & 5 \\
\hline Madagascar & no & ----- & ----- \\
\hline Mauritania & no & ----- & ----- \\
\hline Mali & no & ----- & ----- \\
\hline Mozambique & no & ----- & ---- \\
\hline Niger & no & ----- & ----- \\
\hline Nigeria & no & ----- & ---- \\
\hline Senegal & yes & $1995-1997$ & 3 \\
\hline South Africa & yes & $1995-2005$ & 11 \\
\hline Tanzania & yes & $1995-1996$ & 2 \\
\hline Uganda & yes & 1995 & 1 \\
\hline Zambia & yes & $1995-1997$ & 3 \\
\hline
\end{tabular}

Source: author from WDI 2014.

Table 1. Distribution of health crises in the sample

\begin{tabular}{|c|c|c|}
\hline d_crisis & Frequency & Percentage \\
\hline 0 & 356 & 79.11 \\
\hline 1 & 94 & 20.89 \\
\hline Total & 450 & 100.00 \\
\hline
\end{tabular}

Source: author from stata 13 .

Table 3. Definition of model explanatory variables

\begin{tabular}{|c|c|c|c|}
\hline Notation & Definition & Type of variable & $\begin{array}{c}\text { Expected impact on the occurrence of a health } \\
\text { crisis }\end{array}$ \\
\hline reduc_debt & Debt reduction in volume & Continuous & negative \\
\hline inflation & Inflation rate calculated from the Consumer Price Index & Continuous & positive \\
\hline arriv & Number of international arrivals in the country & Continuous & positive \\
\hline tfert_fonds & Net monetary transfer as\% of GDP & Continuous & negative \\
\hline debt_reserv & the ratio of short-term debt by currency reserves & Continuous & positive \\
\hline corruption & Degree of freedom against corruption & Binary & negative \\
\hline conflict & existence of conflicts & Binary & positive \\
\hline intensity_conflict & Intensity of conflicts & Binary & --------- \\
\hline type_conflict & Type of conflict & Binary & Binary \\
\hline type_financ & Type of organization or funding of the health care & & \\
\hline
\end{tabular}

Source: author 
Most of these data come from the WDI 2014 database of the World Bank. These include debt reduction, the number of international arrivals, transfers of monetary funds, and the ratio of short-term debt by foreign exchange reserves. The variable on the degree of freedom against corruption comes from the online database of the University of Sherbrooke in Canada (world perspective); a high index means that individuals are not condemned to accept corruption. The variables on the existence of conflicts, their intensity and nature, come from UCDP/PRIO Armed Conflict Dataset and the variable on the typology of health care systems in sub-Saharan Africa derives from Van Dormaël ([19]) and Imam and Salinas ([38]).

In the following subsection, we make the mean difference test in order to identify variables that best explain the occurrence of a health crisis.

\subsection{Data Analysis}

The table below shows the statistics for the study variables. The panel data used is highly balanced, i.e. all variables are observed over the same period for each individual.

The results of descriptive statistics show that, apart from the variable "arriv", the rest of the variables are in the same scale. We should transform this variable 'arriv' by using logarithm, but in the case of prediction, if this variable takes the value 0 , it would be impossible to make the forecast. So this variable is left in this state.
In the rest of this subsection, we will identify the variables that best explain health crises in sub-Saharan Africa. To this end, we will do the following analyses: mean difference tests and analysis of correlation.

\subsubsection{Mean Difference Tests}

The table below shows the mean difference tests. There are two types of tests: one based on quantitative variables (Dixon and Massey, [39], Hoel, [40], Acock, [41], Hamilton, [42]) and the other based on qualitative variables (Acock, [41]). The results are confined in Table 5 below.

It appears from this table that the existence of conflicts and their intensity are not determining variables in the explanation of health crises. These variables are therefore excluded from the list of potential explanatory variables for health crises. We continue our analysis with the rest of the variables. But before, we will identify the variables that are correlated with each other in order to solve the problem of multi-collinearity.

\subsubsection{Analysis of the Correlation}

Table 6 below gives the Pearson correlation coefficients (Pearson, [43], Pearson and Filon, [44], Acock, [41]). This table shows that cash transfers are negatively correlated with $5 \%$ threshold at the international arrivals. This can be explained by the fact that the international arrivals create jobs, thus reducing emigration, so reducing the flow of private monetary transfers coming from abroad.

Table 4. descriptive statistics

\begin{tabular}{|c|c|c|c|c|c|}
\hline Variable & Mean & Standard error & Min & Max & Obs. \\
\hline reduc_debt & $-2.39 e+06$ & $9.09 \mathrm{e}+06$ & $-1.10 \mathrm{e}+08$ & 0 & 450 \\
\hline inflation & 0.0854 & 0.1003 & -0.0962 & 0.8333 & 450 \\
\hline arriv & 701485.8 & 1395523 & 7571.18 & 9600000 & 450 \\
\hline fert_fonds & 0.0386 & 0.0885 & 0.0002 & 0.0620 & 450 \\
\hline debt_reserv & 2.6761 & 14.8289 & 0 & 202.348 & 450 \\
\hline corruption & 1.2511 & 0.4493 & 1 & 3 & 450 \\
\hline conflict & 0.1489 & 0.3564 & 0 & 1 & 450 \\
\hline intensity_conflict & 0.16 & 0.3962 & 0 & 2 & 450 \\
\hline type_conflict & 0.4711 & 1.1386 & 0 & 4 & 450 \\
\hline type_financ & 1.44 & 0.4969 & 1 & 2 & 450 \\
\hline d_crisis & 0.2089 & 0.4070 & 0 & 1 & 450 \\
\hline
\end{tabular}

Source: author from stata 13 .

Table 5. Results of mean difference tests

\begin{tabular}{|c|c|c|c|c|}
\hline Variables & mean & Standard error & statistic & p-value \\
\hline reduc_debt & $-2.17 \mathrm{e}+08$ & $1.05 \mathrm{e}+08$ & $-2.0616^{\mathrm{a}}$ & 0.0398 \\
\hline inflation & -0.0280 & 0.0116 & $-2.4167^{\mathrm{a}}$ & 0.0161 \\
\hline arriv & -464602.8 & 161268 & $-2.8809^{\mathrm{a}}$ & 0.0042 \\
\hline tfert_fonds & -0.0269 & 1.0191 & $-2.6448^{\mathrm{a}}$ & 0.0085 \\
\hline debt_reserv & -9.2957 & 166.4546 & $-5.5845^{\mathrm{a}}$ & 0.0000 \\
\hline corruption & -0.3684 & 0.0552 & $-7.3258^{\mathrm{b}}$ & 0.0000 \\
\hline conflict & 0.0672 & 0.0361 & $1.6273^{\mathrm{b}}$ & 0.1037 \\
\hline intensity_conflict & 0.0543 & 0.0387 & $1.2779^{\mathrm{b}}$ & 0.2013 \\
\hline type_conflict & 0.1921 & 0.0549 & $3.3185^{\mathrm{b}}$ & 0.0009 \\
\hline type_financ & -0.2238 & 0.0564 & $-3.8873^{\mathrm{b}}$ & 0.0001 \\
\hline
\end{tabular}

Source : author from stata $13 .{ }^{\mathrm{a}}$ means student's law and ${ }^{\mathrm{b}}$ normal law. 
Table 6. Correlation matrix (Pearson)

\begin{tabular}{|c|c|c|c|c|}
\hline & Inflation & tfert_fonds & detbt_reserv & reduc_debt \\
\hline inflation & 1.0000 & & & \\
\hline tfert_fonds & -0.0639 & 1.0000 & & \\
\hline debt_reserv & -0.0177 & -0.0703 & 1.0000 & \\
\hline reduc_debt & -0.0033 & 0.0154 & 0.0343 & 1.0000 \\
\hline arriv & -0.0167 & $\mathbf{0 . 0 9 4 6 *}$ & -0.0484 & 0.0371 \\
\hline
\end{tabular}

Source: Author from the study data. * Means significant at the 5\%

Table 7 shows the results of the concordance tests (Cohen, [45]; Altman, [46]) between the corruption variables, the type of health care system and type of conflict. The table shows that corruption is correlated with the type of conflict. The latter is correlated with the type of health care system. Indeed, according to Landis and Koch ([47]), when the kappa statistic is greater than 0.61 , this shows a strong correlation.

Table 2. Matrix of concordance

\begin{tabular}{|c|c|c|c|}
\hline & corruption & type conflict & type financ \\
\hline corruption & --------- & -------- & -------- \\
\hline type conflit & $\mathbf{0 . 9 1 3 0 *}$ & --------- & --------- \\
\hline type financ & -1.1087 & $\mathbf{0 . 6 1 1 6 *}$ & --------- \\
\hline
\end{tabular}

Source: Author from the study data. * Means significant at the 1\%. The statistics are those of Kappa.

Moreover, according to Snedecor and Cochran ([48]), the correlation test between a quantitative variable and a qualitative variable follows Fisher's law. Hence the statistics presented in Table 8 below.

Table 3. Result of correlation $F$ tests

\begin{tabular}{|c|c|c|c|}
\hline Variables & Corruption & Type conflict & Type financ \\
\hline inflation & $15,75^{*}$ & $\mathbf{0 , 6 5}$ & $73,20^{*}$ \\
\hline arriv & $38,64^{*}$ & $\mathbf{1 , 8 7}$ & $75,39^{*}$ \\
\hline tfert_fonds & $7,54^{*}$ & $\mathbf{0 , 3 3}$ & $11,20^{*}$ \\
\hline debt_reserv & $\mathbf{0 , 6 1}$ & $21,38^{*}$ & $7,43^{*}$ \\
\hline
\end{tabular}

Source: Author from the study data. * Means significantly different at the $1 \%$. The statistics are Fisher.

The results from this table show that corruption is correlated with debt. Moreover, the type of conflict variable is correlated with inflation, international arrivals and monetary transfers. The type of health system is not correlated with any variables.

\subsection{Empirical Model Specification}

On the basis of the previous results, we assert that the logistic law is the best distribution law of the error term in equation 2. Thus, in the case of panel data, the empirical model must take into account the structure of Panel. It is then as follows:

$$
d_{-} \text {crisis }_{i t}{ }^{*}=X_{i t}^{\prime} \beta+\varepsilon_{i t}
$$

where $i=1, \ldots, n$ and $t=1, \ldots, T . i$ is the number of individuals in the panel, $t$ is the temporal dimension. If $\varepsilon_{i t}=v_{i t}+u_{i}$, then we have $d_{-}$crisis $_{i t}{ }^{*}=X_{i t}^{\prime} \beta+v_{i t}+u_{i}$, with:

$$
\begin{aligned}
\operatorname{Pr}\left(d_{-} \text {crisis }_{i t}=1\right) & \left.=\operatorname{Pr}\left(d_{-} \text {crisis }_{i t}^{*}\right\rangle 0\right) \\
& \left.=\operatorname{Pr}\left(v_{i t}\right\rangle-X_{i t}^{\prime} \beta-u_{i}\right)
\end{aligned}
$$

Where $v_{i t}$ and $u_{i}$ are independent random variables with $E\left[v_{i t} \mid X\right]=0$

$\operatorname{cov}\left[v_{i t}, v_{j s} \mid X\right]=\operatorname{var}\left[v_{i t} \mid X\right]=1$, if $i=j$ and $t=s ; 0$ otherwise $E\left[u_{i} \mid X\right]=0$

$\operatorname{cov}\left[u_{i}, u_{j} \mid X\right]=\operatorname{var}\left[u_{i} \mid X\right]=\sigma_{u}^{2}$ if $i=j ; 0$ otherwise, $\operatorname{cov}\left[v_{i t}, u_{j} \mid X\right]=0$ for all $i, t, j$ and $\mathrm{X}$ indicates all the exogenous data in the sample, $X_{i t}$ for all $i$ and $t$. Then,

$$
\begin{gathered}
E\left[\varepsilon_{i t} \mid X\right]=0 \\
\operatorname{Var}\left[\varepsilon_{i t} \mid X\right]=\sigma_{v}^{2}+\sigma_{u}^{2}=1+\sigma_{u}^{2}
\end{gathered}
$$

And

$$
\operatorname{corr}\left[\varepsilon_{i t}, \varepsilon_{i, s} \mid X\right]=\rho=\frac{\sigma_{u}^{2}}{1+\sigma_{u}^{2}}
$$

The joint density of the $v_{i t}$ 's can be obtained by integrating $u_{i}$ out of the joint density of $\left(\varepsilon_{i}, \ldots, \varepsilon_{i T}, u_{i}\right)$ so that :

$$
f\left(\varepsilon_{i 1}, \varepsilon_{i 2} \ldots, \varepsilon_{i T}, u_{i}\right)=f\left(\varepsilon_{i 1}, \ldots, \varepsilon_{i T} \mid u_{i}\right) f\left(u_{i}\right)
$$

Hence,

$f\left(\varepsilon_{i 1}, \varepsilon_{i 2} \ldots, \varepsilon_{i T}\right)=\int_{-\infty}^{+\infty} f\left(\varepsilon_{i 1}, \varepsilon_{i 2} \ldots, \varepsilon_{i T} \mid u_{i}\right) f\left(u_{i}\right) d u_{i}$

Conditioned on $u_{i}$, the $\varepsilon_{i t}$ 's are independent, so,

$$
f\left(\varepsilon_{i 1}, \varepsilon_{i 2} \ldots, \varepsilon_{i T}\right)=\int_{-\infty}^{+\infty} \prod_{t=1}^{T} f\left(\varepsilon_{i t} \mid u_{i}\right) f\left(u_{i}\right) d u_{i}
$$

$\varepsilon_{i t}$ is i.i.d and follows a logistic law $\Lambda$ with a mean of zero and a variance $\sigma^{2}=\frac{\pi^{2}}{3}$ so that

$$
\Lambda(z)=\frac{1}{1+e^{(-Z)}}
$$

where $Z=X_{i t}^{\prime} \beta+u_{i}$ 
$\varepsilon_{i t}$ is independent of $u_{i}$ (the random effect) which follows a normal law $N\left(0, \sigma_{u}^{2}\right)$.

Following Naylor and Smith ([49]) and Skrondal and Rabe-Hesketh ([50]), we state that:

$$
L_{i}=\operatorname{Pr}\left(d_{-}{ }^{c r i s i s_{i 1}}, \ldots, d_{-}{ }^{c r i s i s_{i T}} \mid X_{i 1}, \ldots, X_{i T}\right)=\int_{-\infty}^{\infty} \frac{e^{-u_{i}^{2} / 2 \sigma_{u}^{2}}}{\sqrt{2 \pi} \sigma_{u}}\left\{\prod_{t=1}^{T} \frac{1}{1+e^{\left(-\left(X_{i i}^{\prime} \beta+u_{i}\right)\right)}}\right\} d u_{i}
$$

With:

$$
f\left(u_{i}\right)=\frac{e^{-u_{i}^{2} / 2 \sigma_{u}^{2}}}{\sqrt{2 \pi} \sigma_{u}} \text { and } f\left(\varepsilon_{i t} \mid u_{i}\right)=\frac{1}{1+e^{\left(-\left(X_{i t}^{\prime} \beta+u_{i}\right)\right)}} .
$$

We have to predict the occurrence of health crisis based on the explanatory variables. The explanatory variables are known before the occurrence of health crisis appears, so we use a dynamic model. In the line of this logic and according to Greene ([51]), the log likelihood takes the following form:

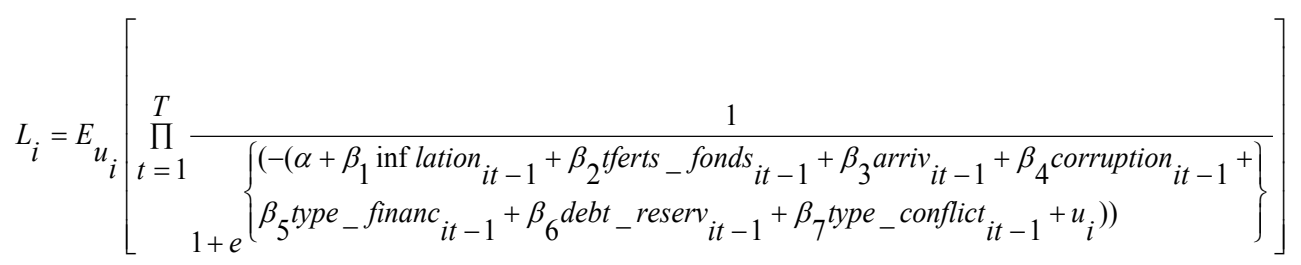

Monetary transfers and the variable international arrivals should not be included in the same equation. The same is true for the corruption variable and the type conflict variable. The latter should not be combined with the type of health care system variable. Moreover, corruption and debt should not be in the same equation. The variable, type of conflict should not be in the same equation as inflation, international arrivals and monetary transfers.

For a given equation where macroeconomic and non-macroeconomic variables are correlated, we will favor macroeconomic variables (Audibert and al., [26]). In the case where the explanatory variables are either macroeconomic or non-macroeconomic, we will rely on the mean difference tests to choose the variable to be retained (Berthélemy, [52]).

Finally we have:

$$
L_{i}=E_{u_{i}}\left[\prod_{t=1}^{T} \frac{1}{\left\{\begin{array}{l}
\left(-\left(\eta+\gamma_{1}\right. \text { inf lation }\right. \\
\text { it }-1 \\
\left.\left.\gamma_{3} \text { type }_{-} \text {financ }_{i t-1}+\gamma_{4} \text { arriv }_{i t-1} \text { debt }_{-} \text {reserv }_{i t-1}+u_{i}\right)\right)
\end{array}\right\}}\right]
$$

\subsection{Estimation Method}

The estimator is the maximum likelihood. We will also use the statistic $\rho=\frac{\sigma_{u}^{2}}{\sigma_{u}^{2}+\sigma_{v}^{2}}$ as a diagnostic tool to find out if the estimation of the parameters by the maximum likelihood estimator, considering the random effects, is more appropriate than a maximum likelihood estimate based on pooling method. $\rho$ is the proportion of variance explained by the panel structure. If it tends to 1 , it means that the structure of the panel is better suited compared to pooling. Otherwise, the panel estimator is not different from the pooling model. 


\section{Results of Estimates and Forecasts}

In this subsection, we show the results of estimates and forecasts on the probability for a country to fall into a health crisis.

\subsection{Results of Estimates}

The results of the estimates from equation 8 are shown in Table 9 below. This table shows that the variables that were ultimately retained are inflation, the number of tourists arriving, the type of health care system, and the ratio of short-term debt to total foreign exchange reserves.

Table 4. Results of estimates

\begin{tabular}{|c|c|c|}
\hline Independent variables & Model 1 & Model 2 \\
\hline \multirow{2}{*}{ inflation } & & $\mathbf{3 . 8 8 7 6 *}$ \\
\cline { 2 - 3 } arriv & $\mathbf{- 8 . 9 8 e - 0 6 * * *}$ & $\mathbf{( 2 . 2 5 0 1 )}$ \\
\cline { 2 - 3 } & $\mathbf{( 6 . 7 1 e - 0 7 )}$ & $\mathbf{- 9 . 0 0 e - 0 6 * * *}$ \\
\hline \multirow{2}{*}{ type_financ } & $\mathbf{1 4 . 6 8 7 3 * * *}$ & $\mathbf{9 . 6 7 6 6 * * * *}$ \\
\cline { 2 - 3 } & $\mathbf{( 2 . 5 6 2 9 )}$ & $\mathbf{( 2 . 4 7 6 8 )}$ \\
\hline \multirow{2}{*}{ debt_reserv } & $\mathbf{0 . 0 8 1 5 * *}$ & $\mathbf{0 . 0 8 2 4} * *$ \\
\cline { 2 - 3 } & $\mathbf{( 0 . 0 4 1 3 )}$ & $\mathbf{( 0 . 0 4 1 9 )}$ \\
\hline \multirow{2}{*}{ Cons } & $\mathbf{- 1 0 . 5 0 9 1 * * *}$ & $\mathbf{- 1 0 . 2 3 1 8 * * *}$ \\
\cline { 2 - 3 } & $\mathbf{( 1 . 4 2 1 2 )}$ & $\mathbf{( 1 . 3 1 9 1 )}$ \\
\hline \multirow{3}{*}{$\begin{array}{c}\text { log likelihood } \\
\text { p-value } \\
\text { rho (fraction of variance } \\
\text { due to u_i) }\end{array}$} & $\mathbf{- 1 2 9 . 3 3 1 1}$ & $\mathbf{- 1 2 8 . 1 2 6 4}$ \\
\cline { 2 - 3 } Number of observations & $\mathbf{0 . 0 0 0 0}$ & $\mathbf{0 . 0 0 0 0}$ \\
\cline { 2 - 3 } & $\mathbf{0 . 9 8 7 7}$ & $\mathbf{0 . 9 8 9 0}$ \\
\cline { 2 - 3 } & $\mathbf{4 1 0}$ & $\mathbf{4 1 0}$ \\
\hline
\end{tabular}

Source: author from the study data. () standard error.
It appears from this table that model 1 has a higher explanatory power than model 2 . Indeed, the test of the likelihood ratio following $\chi^{2}(1)$ in terms of comparison between the two equations gives a calculated value equal to 2.41. This value is smaller than the tabulated value which is equal to 3.841 at the $5 \%$. Moreover, the statistic $\rho$ is high and close to 1 . This means that the panel estimator is more appropriate than the pooling estimator.

The variables arriv and fin_type are positively significant at the $1 \%$. However, the sign of the arriv variable is not the expected one. The reserv_debt variable is significant at the 5\% threshold and has the expected sign.

In sum, the privatization of health care services and the ratio of short-term debt to total foreign exchange reserves favor health crisis in the presence of an unforeseen events. Having a highly privatized health care system leads to more exposure to health crises when an unforeseen events is triggered. The international arrivals during the outbreak of an unforeseen events tends to reduce the risk of a health crisis.

\subsection{Forecast Results}

Table 10 below shows the probability of a health crisis occurring in some countries in sub-Saharan Africa in 2014 and 2015. Countries with a high probability in 2014 and 2015 are Sierra Leone (97.0215\% in 2014, compared to $97.7826 \%$ in 2015) and Nigeria (22\% in 2014).

Table 5. Probability of occurrence of a health crisis in some countries in sub-Saharan Africa

\begin{tabular}{|c|c|c|}
\hline Country & year & Probability (\%) \\
\hline \multirow{2}{*}{ Benin } & 2014 & 0.0004 \\
\hline & 2015 & 0.0003 \\
\hline \multirow{2}{*}{ Côte d'Ivoire } & 2014 & 0.0001 \\
\hline & 2015 & $3.97258 \mathrm{E}-05$ \\
\hline \multirow{2}{*}{ Guinea } & 2014 & 0.0017 \\
\hline & 2015 & 0.0021 \\
\hline \multirow{2}{*}{ Sierra Leone } & 2014 & 97.0215 \\
\hline & 2015 & 97.7826 \\
\hline \multirow{2}{*}{ Senegal } & 2014 & $1.9512 \mathrm{E}-07$ \\
\hline & 2015 & $1.4982 \mathrm{E}-06$ \\
\hline \multirow{2}{*}{ South Africa } & 2014 & $4.3653 \mathrm{E}-34$ \\
\hline & 2015 & $3.9724 \mathrm{E}-34$ \\
\hline \multirow{2}{*}{ Congo, Rep. } & 2014 & 0.0001 \\
\hline & 2015 & $5.7123 \mathrm{E}-05$ \\
\hline \multirow{2}{*}{ Botswana } & 2014 & 0.0062 \\
\hline & 2015 & ------- \\
\hline \multirow{2}{*}{ Zimbabwe } & 2014 & 0.0007 \\
\hline & 2015 & 0.0004 \\
\hline \multirow{2}{*}{ Zambia } & 2014 & 1.7735 \\
\hline & 2015 & 1.3352 \\
\hline & 2014 & 22.9737 \\
\hline \multirow[t]{2}{*}{ Nigeria } & 2015 & |------ \\
\hline & 2014 & 1.0915 \\
\hline Swaziland & 2015 & ------ \\
\hline
\end{tabular}

Source: author, based on the Model 1 parameters and WDI 2016 data. 
The fact is that these countries generally have probability of occurrence of health crisis that have increased over the period 2014-2015 and have inherited an Anglo-Saxon health care system strongly dominated by the privatization of health care (Van Dormaël, [19]).

\subsection{Discussion}

The international arrivals negatively impacts the occurrence of a health crisis. While in theory, international migratory flows favor health crises through the spread of viruses (Farmer, [24]); this may be explained by the fact that the international arrivals lead to an increase in activities and, consequently, an increase in income leading to a reduction in poverty and, therefore, the vulnerability of populations to infectious diseases. In addition, the international arrivals during the outbreak of unforeseen events lead to serenity among the population, which is reinforced by the currency entry.

This may explain why Guinea, which is a country with a low probability of occurrence of health crises, was the first country in West Africa to be vulnerable to Ebola virus in 2014 followed by Sierra Leone. Indeed, during the outbreak of the epidemic in 2014, the information was not well managed to avoid panic. According to World Bank data, the number of arrivals went from 56,000 in 2013 to 33,000 in 2014. Yet in Senegal, where there has also been a case, the number of arrivals has increased; going from 962,000 in 2013 to $1,063,000$ in 2014 .

\section{Conclusion and Recommendations}

The aim of this article was to identify the macroeconomic determining factors of health crises. To achieve this goal, we used a logit model on a panel of 25 sub-Saharan African countries over the period 1995-2012. We also used statistical methods to select the macroeconomic variables that explain the occurrence of health crises. The results of this study show that the macroeconomic variable that explains the occurrence of health crises at the outbreak of unforeseen events is the ratio of debt to total foreign exchange reserves. As for the non-macroeconomic variables, we have the international arrivals and the type of organization of the health care system that prevails.

Among these variables, the most important is the type of health care system. However, at the triggering of the epidemic of Ebola hemorrhage, it was the variable international arrivals that led Guinea and Sierra Leone to vulnerability.

These results imply that, beyond macroeconomic management, managing information about epidemics and others unforeseen events is very crucial in resilience to health crises. Moreover, in the event of an outbreak of unforeseen events, the privatization of health care favors the emergence of health crises, because it prevents the poorest from quality care.
At the end of these results, we recommend a better management of information about the unforeseen events, the increase of exportations and the improvement of accessibility for all to health services during the triggering of unforeseen events.

\section{Acknowledgements}

I would like to thank AfHEA for the opportunity she gave us in presenting the results of our article at the conference it organized in 2016 in Rabat, Morocco. The criticisms have been very useful and has made it possible to adjust certain elements of this study.

\section{REFERENCES}

[1] Toma B., \& Thiry E. (2003), « Qu'est-ce qu'une maladie émergente ? », Epidemiol. Santé Anim., 44, 1-11.

[2] Baylet, R. (2005), « Des Crises Sanitaires par émergence d'agents biologiques nouveaux ", Académie des Sciences et Lettres de Montpellier, Séance du 11/04/2005, Conférence $\mathrm{N}^{0}$ 3904.

[3] Couderc, N., Drouhin, N. \& Ventelou, B. (2006), « SIDA et croissance économique: le risque d'une « trappe épidémiologique » ", Revue d'économie politique, 2006/5 Vol. 116, p. 697-715.

[4] Poku, K., N. (2002), « Poverty, Debt and Africa's HIV/AIDS Crisis », International Affairs (Royal Institute of International Affairs 1944-), Vol. 78, No.3 (Jul., 2002), pp. 531-546.

[5] Dayton-Johnson, J. (2006), « Catastrophes Naturelles et Vulnérabilité », Cahier de Politique Économique $\mathrm{N}^{\circ} 29$, OCDE.

[6] Subramanian, S. V., Belli, P. \& Kawachi, I. (2002), « The Macroeconomic Determinants of Health », Annu. Rev. Public Health, 2002. 23:287-302.

[7] Sirven, N. (2007), « De la pauvreté à la vulnérabilité : évolutions conceptuelles et méthodologiques », Mondes en développement, 2007/4 n 140, pages 9 à 24 .

[8] Rebaudet, S. \& Piarroux, R. (2013), « Origine et déterminants de l'épidémie de cholera 2012 en République de Guinée », UNICEF \& APHM. Rapport Final.

[9] Genberg, H. (1990), " Ajustement Macroéconomique et Secteur de la santé: Revue de la Littérature », Institut Des Hautes Études Internationales, Genève, Suisse.

[10] Logie, D. \& Rowson, M. (1998), « Poverty and Health: Debt Relief Could Help Achieve Human Rights », Health and Human Rights, Vol. 3, No. 2, Fiftieth Anniversary of the Universal Declaration of Human Rights (1998), pp. 82-97.

[11] Touzé, V. \& Ventelou, B. (2002), « SIDA et développement : un enjeu », Revue de l'OFCE, mars.

[12] Guillaumont, P., Korachais, C. \& Subervie (2009), « Comment l'instabilité macroéconomique diminue la survie des enfants », Revue d'économie du développement 2009/1, Vol. 17), p.9-32. 
[13] Grossman M. (1972), "On the concept of health capital and the demand for health", Journal of Political Economy; vol. 80, $n^{\circ} 2$.

[14] Pritchett, L. and Summers L. H., (1996), "Wealthier is healthier", Journal of Human Ressources 31: 844-68.

[15] Bloom, D. E. \& Canning, D. (2000), "The Health and Wealth of Nations", Science, Vol. 287, 18 February 2000.

[16] Deaton A. (2006), "Global Patterns of Income and Health: Facts, Interpretations, and Policies," NBER Working Papers 12735, National Bureau of Economic Research, Inc.

[17] Boidin, B. \& Lardé, P. (2010), « Santé et trappes de sous-développement humain en Afrique ", Economie appliquée, t. LXIII, No 2, juin, p. 123-150.

[18] Basu, S., Mate, K., Farmer, P.E. (2000), « Debt and poverty turn a disease into an epidemic », Nature, 407(September): 17.

[19] Van Dormaël, M. (1997), « La médecine coloniale, ou la tradition exogène de la médecine moderne dans le Tiers Monde ", Studies in Health Services Organisation \& Policy, $1,1997$.

[20] Bachand, R. (2004), «Privatisation des soins de santé en Afrique: Une solution miracle au bénéfice (et au détriment) de qui ? ", Canadian Journal of African Studies / Revue Canadienne des Études Africaines, Vol.38, No. 1 (2004), pp. $1-19$.

[21] Birchenal, J. A. (2007), « Escaping High Mortality », Journal of Economic Growth, Vol. 12, N .4 (Dec., 2007), pp.351-387.

[22] Sala-i-Martin, X (2005), « On the Health Poverty Trap », In López-Casasnovas G, Rivera B. and Currais L. (eds.) Health and Economic Growth: Findings and Policy Implications. Cambridge, MA, USA: MIT Press.

[23] Briggs, L. C., (2001), « Modernity, Cultural Reasoning, and the Institutionalization of Social Inequality: Racializing Death in a Venezuelan Cholera Epidemic ", Comparative Studies in Society and History, Vol. 43, No. 4 (Oct., 2001), pp. 665-700.

[24] Farmer, P. (1996), « Social Inequalities and Emerging Infectious Diseases », Emerging Infectious Diseases Vol. 2, No. 4-October-December 1996.

[25] Mookherjee D. (1997), « Incentive reforms in developing country bureaucracies - Lessons from tax administration », Paper for the Annual Bank Conference on Development Economics, World Bank.

[26] Audibert M., Mathonnat, J. \& De Rootenbeke, E. (2003), «Le financement de la santé dans les pays d'Afrique et d'Asie à faible revenu », Karthala Editions.

[27] Chauvet, L. (2001) « Socio-political instability and the allocation of international aid by donors ", European Journal of Political Economy, Vol. 19 (2002) 33 - 59.

[28] Miguel, E., Satyanath, S. \& Sergenti, E. (2004), « Economic shocks and civil conflit: An instrumental Variables Approach ", Journal of political Economy, Vol. 112, n ${ }^{\circ} 4$.

[29] Temah, T. C. (2009), «Les Déterminants de l'épidémie du VIH/SIDA en Afrique Subsaharienne », Revue d'économie du développement, 2009/1 Vol. 17, pages 73-106.

[30] UNDESA (2007), « Politique macroéconomique et politique de croissance », Initiative for Policy Dialogue (IPD),
Columbia University, New York, Nations Unies Département des affaires économiques et sociales (DAES/ UNDESA) -2007- stratégies nationales de developpement, Notes d'orientation.

[31] Stillwaggon, E. (2002), «HIV/AIDS in Africa: Fertile Terrain », Journal of Development Studies, vol. 38(6), p. 1-22.

[32] Xu, K., \& Saksena, P. (2011). The determinants of health expenditure: A country level panel data analysis. Geneva: World Health Organisation (WHO).

[33] Farag, M., NandaKumar, A. K., Wallack, S., Hodgkin, D., Gaumer, G., \& Erbil, C. (2012), «The income elasticity of health care spending in developing and developed countries ", International Journal of Health Care Finance and Economics, $12,145-162$.

[34] The World Bank. (2009). Protecting pro-poor health services during financial crises-Lessons from experience. Washington, DC: The World Bank.

[35] Hailua, D. \& Shiferawb, A. (2016), « Determinants of 'Exit' from High Aid- Dependence », Journal of African Economies, 2016, Vol. 25, number 5, 670-698.

[36] Manasse, P., Roubini, N. \& Schimmelpfennig, A. (2003), « Predicting sovering Debt Crises », IMF Working Paper $\mathrm{WP} / 03 / 221$

[37] Van Dormaël, M. (1997), « La médecine coloniale, ou la tradition exogène de la médecine moderne dans le Tiers Monde ", Studies in Health Services Organisation \& Policy, $1,1997$.

[38] Imam, P. \& Salinas, G. (2008), « Explaining Episodes of Growth Accelerations, Decelerations and Collapses in Western Africa », IMF Working Paper, Paper WP/08/287.

[39] Dixon, W. J., \& F. J. Massey, Jr. (1983), « Introduction to Statistical Analysis », 4th ed. New York: McGraw-Hill.

[40] Hoel, P. G. (1984), «Introduction to Mathematical Statistics », 5th ed. New York: Wiley.

[41] Acock, A. C. (2012), «A Gentle Introduction to Stata », rev. 3rd ed. College Station, TX: Stata Press.

[42] Hamilton, L. C. (2013), « Statistics with Stata: Updated for Version $12 »$, 8th ed. Boston: Brooks/Cole.

[43] Pearson, K. (1896), « Mathematical contributions to the theory of evolution-III. Regression, heredity, and panmixia ", Philosophical Transactions of the Royal Society of London, Series A 187: 253-318.

[44] Pearson, K., \& L. N. G. Filon. (1898), « Mathematical contributions to the theory of evolution. IV. On the probable errors of frequency constants and on the influence of random selection on variation and correlation ", Philosophical Transactions of the Royal Society of London, Series A 191: 229-311.

[45] Cohen, J. (1960), « A coefficient of agreement for nominal scales ", Educational and Psychological Measurement 20: 3746 .

[46] Altman, D. G. (1991), « Practical Statistics for Medical Research », London: Chapman \& Hall/CRC.

[47] Landis, J. R., \& G. G. Koch. (1977), « The measurement of 
observer agreement for categorical data ». Biometrics 33: 159174.

[48] Snedecor, G. W., \& W. G. Cochran. (1989), « Statistical Methods », 8th ed. Ames, IA: Iowa State University Press.

[49] Naylor, J. C., \& A. F. M. Smith. (1982), « Applications of a method for the efficient computation of posterior distributions ", Journal of the Royal Statistical Society, Series C 31: 214225 .
[50] Skrondal, A., \& S. Rabe-Hesketh. (2004), « Generalized Latent Variable Modeling: Multilevel, Longitudinal, and Structural Equation Models », Boca Raton, FL: Chapman \& Hall/CRC.

[51] Greene, W. H. (2012), «Econometric Analysis », Prentice Hall, Seventh Edition.

[52] Berthélemy, J-C., (2007), « Human capital and emergence from development trap », Mimeo, Université Paris 1 Panthéon Sorbonne. 